\title{
Can conscious guilt feelings incite nocebo pain?
}

\author{
Suçluluk duyguları nosebo ağrı tepkilerini güçlendirebilir mi?
}

\author{
(1) Kutlu Kağan TÜRKARSLAN, (D) Deniz Canel ÇINARBAŞ
}

\begin{abstract}
Summary
Objectives: Psychodynamically, chronic pain problems with no organic cause have been conceptualized as a punishment through physical pain for guilt feelings. This study aimed to investigate the effects of conscious guilt feelings on nocebo pain responses and whether the resultant nocebo pain would affect conscious guilt feelings in the form of expiation through the pain.
\end{abstract}

Methods: An experiment was conducted with 100 participants. There were two independent variables, which were guilt induction (guilt-no guilt) and nocebo manipulation (nocebo-no nocebo). Nocebo manipulation was done by telling the participants that they would receive electricity from an EEG cap. In addition, they watched a video in which a confederate imitates having pain during the procedure. There were two dependent variables, guilt feelings, and experienced pain. Guilt feelings were measured using Positive and Negative Affect Scale twice, once after guilt induction and once after nocebo pain manipulation. Subjective pain scores were measured by using a basic 0 to 10 visual pain scale, on which the participants reported how much pain they experienced.

Results: The findings revealed that only the main effect of nocebo was significant.

Conclusion: The participants reported mild headaches in the absence of any physical stimulation after nocebo manipulations. The effect was observed in a standard laboratory environment. Non-physical nocebo pain induction could create pain, but conscious guilt induction did not increase the amount of reported nocebo pain, and resultant pain did not function as a punishment. Limitations and implications of the study were discussed.

Keywords: Expectation; guilt; headache; nocebo effect; punishment.

\section{Özet}

Amaç: Organik sebepleri tespit edilemeyen kronik ağrı problemleri psikodinamik literatürde, kişinin fiziksel ağrıyı kullanarak hissettiği suçluluk duyguları sebebiyle kendisini cezalandırması orası olarak kavramsallaştıııımıştır. Bu çalışmanın amaçları bilinçli suçluluk duygularının nocebo ağrılarının oluşumu üzerindeki etkilerinin ve ortaya çıkan nocebo ağrılarının bilinçli suçluluk duyguları üzerindeki etkisinin incelemektir.

Gereç ve Yöntem: Bu çalışmada deney 100 katılımcı ile yürütülmüştür. Çalışmanın suçluluk uyandırılması ve nocebo manipülasyonu olmak üzere iki bağımsız değişkeni vardır. Nocebo manipülasyonu katılımcılara başlarında taktıkları bir EEG şapkasından kendilerine elektrik verileceğinin söylenmesi ve ağrı çekiyormuş gibi taklit yapan bir katılımcının bu prosedürü gerçekleştirirken ki videosunun izletilmesiyle yapılmıştır. Çalışmanın bağımlı değişkenleri suçluluk duyguları ve nocebo manipülasyonu sonrası deneyimlenen ağrıdır. Suçluluk duygularını Pozitif ve Negatif Duygu Ölçeği kullanılarak ilk olarak suçluluk uyandırıması sonrası, daha sonra nocebo manipülasyonu sonrası iki kere ölçülmüştür. Suçluluk duyguları katılımcılara ne kadar ağrı hissettiklerini 0 ile 10 arasında göstermelerini isteyen basit görsel bir ölçekle ölçülmüştür.

Bulgular: Yapılan analizler sonucu sadece nocebo değişkeninin ana etkisi anlamlı bulunmuştur.

Sonuç: Katılımcılar herhangi bir fiziksel uyarıma maruz kalmadan hafif baş ağrısı deneyimlediklerini rapor etmişlerdir. Bu etki standart bir laboratuvar ortamında gözlemlenmiştir. Bilinçli suçluluk duygularının hissedilen nocebo ağrısını üzerinde anlamlı bir etkisi olmadığı bulunmuştur. Ayrıca ortaya çıkan nocebo ağrısı bir cezalandırma işlevi gördüğünü hipotezi de desteklenememiştir. Çalışmanın kısıtlılıkları ve implikasyonları tartışımıştır.

Anahtar sözcükler: Beklenti; suçluluk; baş ağrısı; nocebo etkisi; cezlandırma.

The article was generated from the master thesis that the first author produced in supervision of the second author.

Department of Psychology, Middle East Technical University, Ankara, Turkey

Submitted (Başvuru tarihi) 11.06.2019 Accepted after revision (Düzeltme sonrası kabul tarihi) 13.01.2020 Available online date (Online yayımlanma tarihi) 04.05.2020

Correspondence: PhD Stu. Kutlu Kağan Türkarslan. Orta Doğu Teknik Üniversitesi, Psikoloji Bölümü, 06800 Ankara, Turkey.

Phone: +90 - 312 - 2105110 e-mail: kutlu.turkarslan@metu.edu.tr

(c) 2020 Turkish Society of Algology 


\section{Introduction}

Chronic pain can be regarded as a widespread health problem. Percentages of people suffering from chronic pain range between $11 \%$ and $63.7 \%$, depending on the population investigated and the methodology used. ${ }^{[1-6]}$ Unfortunately, chronic pain problems propose a challenge for physicians, especially in the absence of clear and discernible organic causes. ${ }^{[7]}$

For example, $80 \%$ of back pain problems lacks clear organic diagnosis. ${ }^{[8]}$ Furthermore, studies with follow up assessment revealed that if no underlying organic cause is found as a result of the initial assessment, it is extremely unlikely finding one latter in time. ${ }^{[9]}$ Therefore, in many cases of chronic pain problems, the practitioners assume that there may be an undiscovered and underlying physio-pathological process producing pain, or that the pain is caused by psychological factors. ${ }^{[10]}$

Consequently, even though researchers investigated a long list of risk factors for pain, they have failed to find a prominent physical and psychosocial variable that can adequately explain chronic pain problems. ${ }^{[11]}$ The concept of nocebo pain may shed light on the experience of pain in the absence of organic causes. When individuals expect to experience pain, they indeed may feel pain. In addition, from psychodynamic perspective, it can be asserted that guilt feelings may find a way of expiation through the pain. The purpose of the present study was to investigate the interaction of nocebo pain and guilt feelings.

The concept of nocebo has not been as popular as its sibling, placebo. Concisely, it can be defined as the worsening or occurrence of a symptom in expectation of a negative outcome. ${ }^{[12]}$ In medical terms, it involves a non-pharmacodynamic, noxious, unpleasant, and generally undesirable effect experienced by the person getting an inactive treatment. ${ }^{[13]}$ Acknowledging nocebo effect is a crucial attempt to deepen the understanding of patients' pain experiences. Because, people may have pain without any sensory stimulation or they may experience a nonnoxious stimulus as painful, due to nocebo effects.

For example, in a pioneering study, Schweiger and Parducci ${ }^{[14]}$ told college students that a mild electric current would be given to their heads through an
EEG cap, while doing a task to reduce possible headaches. There was no real electrical stimulation, but two-thirds of 34 students reported mild headaches. In another study by Johansen, Brox, and Flaten, ${ }^{[15]}$ the participants' pain reports increased after injection of a saline solution, which was believed by the participants to be a pain exacerbating solution. Colloca, Sigaudo, and Benedetti ${ }^{[16]}$ were able to turn a nonpainful tactile stimulus into a painful one, and lowintensity pain into high-intensity pain with verbal suggestions or conditioning. Moreover, Vögtle, Barke, and Kröner-Herwig ${ }^{[17]}$ showed that even observational learning might play on a role in nocebo responses. In observational learning condition, the participants were shown a video of a model expressing more pain with the application of an ointment increasing pain and the participants' pain ratings were higher with ointment than without. In control and verbal suggestion conditions, the pain ratings were similar, independent of the application of the ointment.

Interestingly, Jensen et al. ${ }^{[18]}$ conducted two experiments consisting thermal pain stimulus conditioned with two male faces showing that nocebo effect is evident when conditioned stimuli are presented both consciously (100 ms) and unconsciously (stimuli for $12 \mathrm{~ms}$, followed by a visual mask for $84 \mathrm{~ms}$ ). The participants responded to low pain temperature with high cue as if it was high pain temperature. As demonstrated by the results of a meta-analysis involving ten studies, the nocebo effect is found to have a moderate to large effect size (lowest $\mathrm{g}=0.62$ $[0.24-1.01]$ and highest $g=1.03[0.63-1.43]) .{ }^{[19]}$

Underlying biological and neurological mechanisms producing nocebo reactions have been widely studied. Several studies have stressed the role of cholecystokinin in nocebo hyperalgesia through anticipatory anxiety mechanisms. ${ }^{[20,21]}$ Keltner et al. ${ }^{[22]}$ examined the effects of two types of expectancy (high and low) on noxious stimulus via fMRI and found that the ipsilateral caudal, anterior cingulate cortex, the head of the caudate, cerebellum, and the contralateral nucleus cuneiformis were activated distinctly. In anticipation of pain, different levels of activation were spotted at insula, ${ }^{[23]}$ the anterior cingulate cortex, the ventromedial prefrontal cortex, and the periaqueductal grey. ${ }^{[24]}$ To sum up, the nocebo effect is an important concept having real consequences on 
the experience of pain. Expectation and anticipatory anxiety are regarded as the main motivators of nocebo pain responses. Apart from these motivators, psychodynamic perspective suggests that physical pain may provide a way of expiation from the guilt feelings by using pain as a punishment.

Psychodynamic approach has conceptualized roles of shame and guilt in psychopathology more elaborately than other theoretical approaches. ${ }^{[25]}$ Since the publication of Studies of Hysteria, ${ }^{[26]}$ many psychodynamic hypotheses have been proposed about the role of psychological conflicts in the occurrence of some somatic complains, including chronic pain. Sigmund Freud was one of the pioneer thinkers who dealt with guilt feelings and their psychic and behavioral consequences. ${ }^{[27]}$ One of his first mentions of guilt can be found in his work entitled "The defense neuro-psychoses".[28] He discussed symptoms of an obsessive girl who became extremely doubtful that she actually did the bad acts that she read in the newspaper. Even though she acknowledged the absurdity of such obsessions; in time, she began to believe that she did them in real life. Later, in the analysis, Freud traced the causes of these absurd guilty feelings to the girl's sexual relationship with a woman involving masturbation for several years. Here, the guilt can be understood as a strong motivator underlying obsessional symptoms' formation.

Freud thought that guilt could disguise itself in the form of illness or physical symptoms. In his seminal paper, The Ego and The Id, he further contemplated the relationship between guilt and illness:

We finally come to realize that what is involved here is a 'moral' factor, so to speak: a guilt-feeling that finds its gratification in illness and refuses to forgo the punishment that suffering represents. Although this explanation is scarcely cheering, it is one that merits our unwavering support. However, this guiltfeeling remains entirely mute vis-à-vis the patient: it does not tell him he is guilty, and instead of feeling guilty, he feels ill. ${ }^{[29]}$

Moreover, Freud asserted that people try to get rid of guilt feelings by seeking punishment, and this is apparent in childhood. In his essay, "Some CharacterTypes Met with in Psycho-Analytic Work", he wrote:
With children, it is easy to observe that they are often 'naughty' on purpose to provoke punishment, and are quiet and content after they have been punished. Later analytic investigation can often put us on the track of the guilty feeling, which induced them to seek punishment. ${ }^{[30]}$

According to Freud, a more systematic conceptualization of guilt comes after the emergence of the superego. In terms of intrapsychic conflicts, guilt becomes a tool for superego to modulate ego. ${ }^{[31]} \mathrm{Su}$ perego is a societal agent comprising cultural norms and values; in other words, the representative of civilization within. In "Civilization and Its Discontents," Freud remarked the conflict between humans and civilization and role of guilt in this sense:

The tension between the harsh superego and the ego that is subjected to it, is called by us the sense of guilt; it expresses itself as a need for punishment. Civilization, therefore, obtains mastery over the individual's dangerous desire for aggression by weakening and disarming it and by setting up an agency within him to watch over it, like a garrison in a conquered city. ${ }^{[32]}$

Yet, do we feel guilty only when we do something wrong? Freud was dissatisfied with a simple yes answer to this question, and he stated:

To begin with, if we ask how a person comes to have a sense of guilt, we arrive at an answer which cannot be disputed: a person feels guilty (devout people would say 'sinful') when he has done something which he knows to be 'bad.' But then we notice how little this answer tells us. Perhaps, after some hesitation, we shall add that even when a person has not actually done the bad thing but has only recognized in himself an intention to do it, he may regard himself as guilty; and the question then arises of why the intention is regarded as equal to the deed. ${ }^{[33]}$

In summary, Freud was one of the first thinkers to acknowledge that guilt feelings can lead to somatic and non-somatic symptoms in the form of punishment. His ideas later inspired other psychoanalytic scholars such as George L. Engel who theorized about the relationship between chronic pain, psychic conflicts, and object relations. Treating pain 
as a sensory phenomenon, Engel asserted that it might be possible to experience pain without direct sensory stimulation. $\mathrm{He}^{[9]}$ presumed that a person collects a library of pain experiences resulting from peripheral pain stimulations during his or her course of life. Like visual or auditory experiences, they may be activated without any direct sensory stimulation. He proposed several personal meanings of pain experiences by connecting them to development and psyche.

First, pain is a part of our protection system and warns us about possible damage or loss of body parts. ${ }^{[9]}$ Therefore, when pain emerges, it is important to learn and record what is causing pain in that environment and the body parts affected by the pain. The cause and location of pain are the main components of pain memories or the body's pain image. Second, pain is entangled with interpersonal relationships. Because of pain, an infant cries to get help from his or her significant other. Therefore, an association between pain, crying, the soothing response of significant other, and relief of pain may be established. Third, during early childhood, pain and punishment are strongly linked to each other. Pain is generally induced as a form of punishment for children's guilty deeds. Therefore, pain signals that one is bad or guilty, and sometimes a need for expiation through pain may be needed. He stated:

I mention this component first because clinical observation leads me to conclude that guilt, conscious or unconscious, is an invariable factor in the choice of pain as the symptom, as compared to other types of body sensations. Clinically we should expect to find either a long-term background of guilt and an immediate guilt-provoking situation precipitating pain..$^{\left[{ }^{9]}\right.}$

Several scientific studies supported the existence of the link between guilt and the need for punishment as proposed by Engel. For example, participants who wrote about their unethical behaviors of rejecting or ostracizing another person, both held their hand in cold water longer (longer pain duration) and rated their experience as more painful than participants in the control group. ${ }^{[32]}$ Moreover, their guilt feelings were significantly reduced after experiencing the pain. In another study, Nelissen ${ }^{[33]}$ reported that participants administered higher level electrical shocks to themselves when they were with someone whom they felt guilty about.

Therefore, it can be asserted that initiation of psychogenic pain or transformation of acute physical pain into chronic pain may be a way of expiation for conscious and unconscious guilt as suggested by psychodynamic theorists. ${ }^{[9,25,34]}$ Stated differently, guilty feelings may exacerbate pain responses, and in return, pain may alleviate guilt feelings. Previous research focused on the relationship between chronic pain and various variables, such as psychopathology or dominant affective states such as anger, anxiety, and depression. ${ }^{[35-37]}$ Due to the non-experimental nature of previous studies, it is not possible to determine a robust causal relation between affective variables and chronic pain problems, even if clinical observation frequently suggests such links. Therefore, examining the effects of guilt on psychogenic pain experiences and effects of pain experience on guilt feelings, using experimental design may contribute to the theoretical understanding of the relationship between guilt and pain.

The aim of the present study was to test whether conscious guilt feelings can increase the likelihood of reporting pain and severity of subjective pain reports in a non-physical nocebo manipulation and whether conscious guilt feelings alleviate after experiencing nocebo pain. It was hypothesized that non-physical nocebo manipulation would conceive pain, and those who wrote guilt-inducing memories would report more pain compared to those who wrote neutral memories. It was also hypothesized that the guilt feelings of the participants who experienced nocebo pain would be less than guilt feelings of the participant who did not experience pain. Nocebo pain induction was selected to evoke pain because it was found in previous studies that it can produce psychogenic pain sensation without any noxious stimulation.

\section{Material and Methods}

\section{Participants}

The study sample was comprised of 100 students from Middle East Technical University who were invited to participate in the study via departmental online subject pool system. In return for their participation, they received bonus points for their cours- 
Table 1. Table showing four conditions of the study

\begin{tabular}{|c|c|c|c|}
\hline & & \multicolumn{2}{|c|}{ Guilt induction } \\
\hline & & Guilt induction & No guilt induction \\
\hline Nocebo & Nocebo manipulation & $\mathrm{n}=25$ & $n=25$ \\
\hline manipulation & No nocebo manipulation & $\mathrm{n}=25$ & $\mathrm{n}=25$ \\
\hline
\end{tabular}

es. There were 78 female (78\%) and 22 male (22\%) participants with ages ranging between 18 and 33 $(M=21.67, S D=1.92)$. Seventy four of the participants (74\%) were psychology undergraduate students and 26 of the participants (26\%) were undergraduates from various departments at Middle East Technical University.

\section{Design}

The design of the study was $2 \times 2$ independent groups design. There were two independent variables (guilt and nocebo), two dependent variables (pain ratings and pre-post manipulation guilt scores). Each of the four experimental groups had 25 participants (Table 1). The participants were assigned to four conditions by their registration order in the SONA system.

\section{Procedure}

The study was approved by the Research Center for Applied Middle East Technical University. The participants were met by the experimenter, and they were asked to fill out informed consent and demographics forms. In the informed consent form, the participants were told that the study is about the effects of pain and memory on hand-eye coordination. Afterward, they were asked to write about either a memory that involves guilt or a neutral memory consisting of their daily interactions with other people. Then, Positive and Negative Affect Scale ${ }^{[38,39]}$ was given for manipulation check. The sixth item of PANAS measures guilt feelings on a 1 to 5 scale ( $1=$ not at all, $5=$ =xtremely). Participants in the nocebo group received visual, verbal, and video instructions about getting mild electric current from the EEG cap. Multiple methods, such as visual and video instructions were used together to strengthen the effect of manipulation.

First, they were shown a visual statement on the computer. Then, they received a verbal statement from the experimenters that the EGG cap would give mild electric current to their head. Finally, they watched a video in which a confederate with EEG cap appeared to be having pain during the procedure. On the other hand, no nocebo group received only a neutral statement that the EEG cap measures brain waves, and there were no instructions involving electricity being given. Later, the participants were asked to complete a visual task ${ }^{[40]}$ while wearing an EEG cap, to keep them occupied during pain induction. In the task, the participants were asked to estimate the location of a circle moving from the top of the screen to the bottom of it. When the circle reaches half way through the screen, the circle becomes invisible behind a blue wall. The blue wall has another grey circle. The participants decide when the circle will fit exactly to the grey circle by clicking a button. After completing the visual task, the participants were asked to rate how much pain they felt during the procedure on a 0 to 10 scale $(0=$ no pain at all, $10=$ unendurable pain). If they reported pain on the scale (any response different from 0 ), they were verbally asked about the type, location, and description of the pain experience.

Afterward, PANAS forms were given again to check whether guilt scores changed after pain manipulation. Finally, the participants received a debriefing form partially explaining the aim of the study as measuring the effects of guilt, feelings and physical pain on pain perception. At this time, the participants were not informed that the EEG cap did not actually induce electricity, in order to prevent them from sharing this information with prospective participants. Once all the data were collected, the participants were contacted via e-mail and provided with a complete explanation of the study's procedures.

\section{Results}

The data were analyzed with JASP 0.9.2 and SPSS 24. There were no missing values for any of the dependent variables. No multiple outliers were detected. 
Table 2. Descriptives for interaction of guilt and nocebo conditions on square root of pain ratings

\begin{tabular}{lccccrr}
\hline Guilt & Nocebo & Mean & SE & Lower Cl & Upper CI & n \\
\hline No & No & 0.566 & 0.142 & 0.284 & 0.848 & 25 \\
& Yes & 1.075 & 0.142 & 0.793 & 0.356 & 25 \\
Yes & No & 0.588 & 0.142 & 0.870 & 25 \\
& Yes & 0.776 & 0.142 & 0.494 & 1.058 \\
\hline
\end{tabular}

SE: Standard error; Cl: Confidence interval.

Table 3. The results of ANOVA for effects of guilt and nocebo conditions on square root of pain ratings

\begin{tabular}{lcccccc}
\hline Cases & Sum of squares & df & Mean square & $\mathbf{F}$ & $\mathbf{p}$ & $\mathbf{\mathbf { n } ^ { \mathbf { 2 } } \mathbf { p }}$ \\
\hline Guilt & 0.478 & 1 & 0.478 & 0.948 & 0.333 & 0.010 \\
Nocebo & 3.027 & 1 & 3.027 & 6.003 & 0.016 & 0.059 \\
Guilt*Nocebo & 0.642 & 1 & 0.642 & 1.274 & 0.262 & 0.013 \\
Residual & 48.415 & 96 & 0.504 & & & \\
\hline
\end{tabular}

ANOVA: Analysis of variance.

Shapiro-Wilk Test of Normality indicated significant deviation from normality $(\mathrm{W}=0.769, \mathrm{p}<0.001)$. Pain ratings across all groups were distributed non-normally with a kurtosis of 3.518 ( $\mathrm{SE}=0.241$ ), and skewness of 1.656 ( $\mathrm{SE}=0.478$ ). Therefore, square root transformation was conducted on the pain ratings. [41,42] The square root transformation yielded better skewness values than logarithmic transformation. Presented data were not back transformed, because there were only slight range differences between non-transformed and transformed values.

\section{Manipulation check for guilt induction}

In order to check whether guilt induction through writing memories had an effect on guilt scores, an independent t-test was conducted between guilt and no guilt conditions. It was found that guilt scores were significantly higher for the participants who wrote guilt-inducing experiences $(M=3.520, S D=1.129)$ than for the participants who wrote daily interaction experiences $(M=1.560, S D=1.072), t(98)=-8.901$, $\mathrm{p}<0.001,95 \% \mathrm{Cl}[-2.397,-1.523]$. This represented a very strong effect, $d=-1.780$. The guilt manipulation had a significant effect on participants' guilt ratings.

\section{Manipulation check for nocebo induction}

To test whether non-physical nocebo induction had an effect on pain ratings, an independent t-test was conducted on nocebo and no nocebo conditions of pain ratings. It was found that pain ratings were

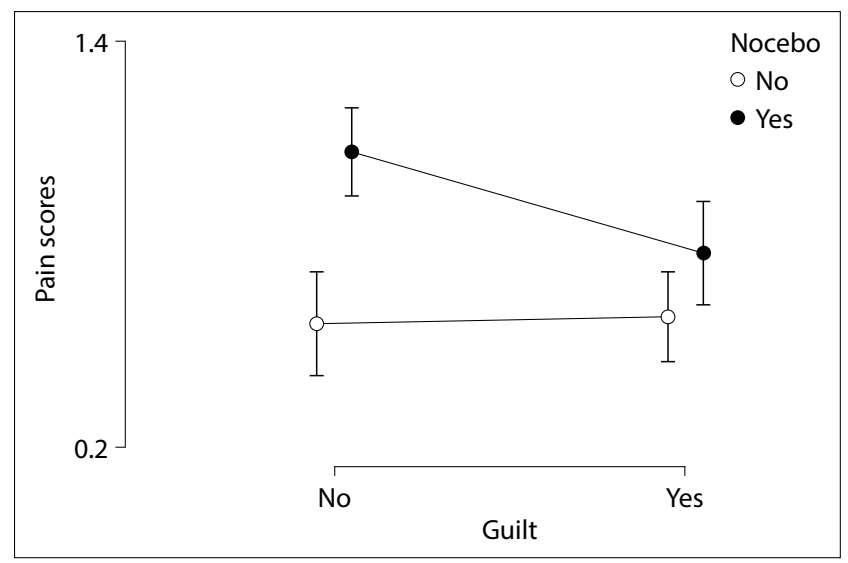

Figure 1. Pain ratings as a function of nocebo and guilt condition. significantly higher for the participants who were exposed to nocebo manipulation $(\mathrm{M}=0.925, \mathrm{SD}=0.717)$ than for the participants who were not exposed to nocebo manipulation $(\mathrm{M}=0.577, \mathrm{SD}=0.705), \mathrm{t}(98)=-$ $2.446, \mathrm{p}=0.016,95 \% \mathrm{Cl}[-0.629,-0.066]$. This represented a moderate effect, $d=-0.489$. The nocebo manipulation had a significant effect on pain ratings of the participants.

\section{The effects of nocebo and guilt on pain ratings}

It was hypothesized that the participants who were in the nocebo condition would report higher levels of pain compared to those in the no-nocebo condition and participants who were asked to write a past guilt-inducing experience would report higher levels of pain in nocebo condition compared to those participants who were asked to write about a neutral 
Table 4. Descriptives for interaction between time and nocebo conditions

\begin{tabular}{lcccccc}
\hline Time & Nocebo & Mean & SE & Lower Cl & Upper CI & $\mathbf{n}$ \\
\hline Pre & No & 3.600 & 0.228 & 3.142 & 4.058 & 25 \\
& Yes & 3.440 & 0.228 & 2.982 & 3.898 & 25 \\
Post & No & 2.280 & 0.208 & 1.863 & 2.697 & 25 \\
& Yes & 2.120 & 0.208 & 1.703 & 2.537 & 25 \\
\hline
\end{tabular}

SE: Standard error; Cl: Confidence interval.

Table 5. The results of repeated measures ANOVA for main effect of time and interaction of time and nocebo

\begin{tabular}{lcccccc}
\hline & Sum of squares & df & Mean square & $\mathbf{F}$ & $\mathbf{p}$ & $\mathbf{\eta}^{\mathbf{2}} \mathbf{p}$ \\
\hline Time & 43.560 & 1 & 43.560 & 82.189 & $<0.001$ & 0.631 \\
Time*Nocebo & $4.333 \mathrm{e}-32$ & 1 & $4.333 \mathrm{e}-32$ & $8.176 \mathrm{e}-32$ & 1.000 & 0.000 \\
Residual & 25.440 & 48 & 0.530 & & & \\
\hline
\end{tabular}

ANOVA: Analysis of variance.

Table 6. The results of ANOVA for main effect of nocebo

\begin{tabular}{lcccccc}
\hline & Sum of squares & df & Mean square & $\mathbf{F}$ & $\mathbf{p}$ & $\mathbf{n}^{\mathbf{2}} \mathbf{p}$ \\
\hline Nocebo & 0.640 & 1 & 0.640 & 0.348 & 0.558 & 0.007 \\
Residual & 88.400 & 48 & 1.842 & & & \\
\hline
\end{tabular}

ANOVA: Analysis of variance.

experience. Two (Nocebo, No-Nocebo) by two (Guilt, No-Guilt) independent groups ANOVA was conducted to examine the interaction. Only the main effect of nocebo was significant, $F(1,96)=6.003, p=0.016$, $\eta \rho^{2}=0.0059$ (Table 2, 3). There was no significant interaction between guilt and nocebo, and the participants in the guilt induction condition did not have higher pain ratings compared to participants in no guilt condition (Fig. 1).

\section{The effects of nocebo and time on guilt feelings}

It was hypothesized that guilt feelings of the participants who were asked to write a past guilt-inducing experience would decrease after having nocebo pain. In other words, there would be an interaction between time and nocebo, no-nocebo conditions on guilt scores. Two (Nocebo, No-Nocebo) by two (Pre nocebo manipulation guilt scores, Post nocebo manipulation guilt scores) mixed ANOVA with repeated measures on the last factor was conducted. Only the main effect of time was significant, $F(1,48)=82.189$, $\mathrm{p}<0.001, \eta \rho^{2}=0.631$ (Table 4-6). There was no significant interaction effect and the participants who

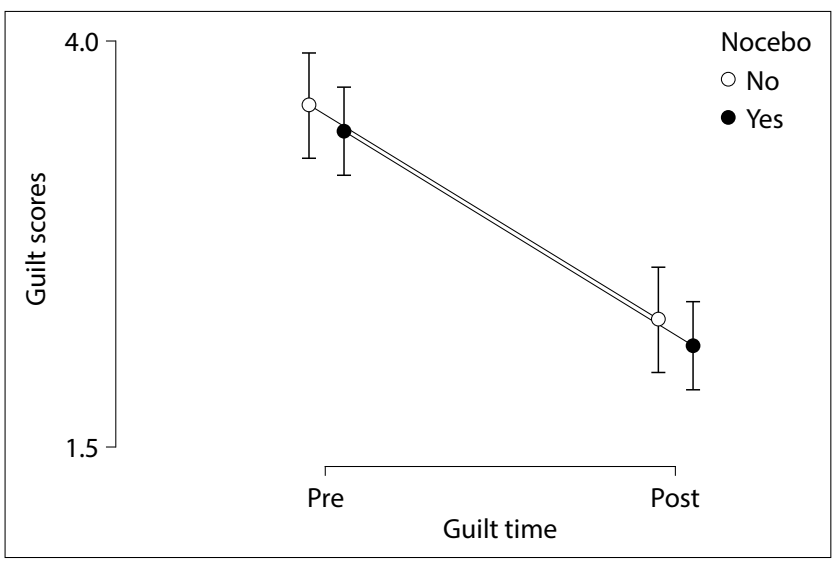

Figure 2. Guilt scores as a function of time and nocebo.

wrote guilt-inducing memories in the nocebo induction condition did not have lower guilt scores than those in the no-nocebo condition (Fig. 2).

\section{Discussion}

The results revealed that participants in the nocebo condition felt more pain, despite no physical pain stimulation, compared to the participants in the nonocebo condition. Therefore, the first hypothesis was supported. Yet, the second hypothesis predict- 
ing that those who wrote guilt-inducing memories would feel more pain than those who wrote neutral memories and third hypotheses predicting that the participants who had nocebo pain would report less guilt than the participants who had no pain was not supported. Stated differently, conscious guilt did not lead to more pain in nocebo manipulation, and nocebo pain did not lead to a decrease in guilt feelings.

Despite moderate to large effect sizes for the nocebo studies, the majority of the previous studies included physical stimulation to create nocebo effect. ${ }^{[18]}$ The only report of nocebo pain induction without any physical stimulation comes from Schweiger and Parducci's study. ${ }^{[14]}$ In their study, two-thirds of the participants reported mild pain after weak and strong nocebo manipulations. The researchers prepared a realistic environment that included a shock inducer, power supply, oxygen tank, noise generator, amplifier, polygraph, brightness comparator consisting of a luminous disc with a concentric surrounding ring, and a dental chair. ${ }^{[14]}$ All these instruments apparently increased suggestibility ${ }^{[43]}$ and anxiety, ${ }^{[19,20]}$ which are underlying mechanisms for nocebo. There were no decorative materials except for an EEG cap and a computer in the present study, yet the nocebo effect could still be created without any physical stimulation.

One possible explanation about successful nocebo manipulation could be demand characteristics, ${ }^{[44]}$ which means the participants behave in ways to satisfy the expectations of the researchers. Yet in the current study, if the participants reported any level of pain, they were asked to define their pain and its location. This procedure may have prevented reporting of pain due to demand characteristics.

Second and third hypotheses of the study were not supported. The findings of the present study failed to support Engel's argument that conscious guilt feelings may lead to psychogenic pain. His clinical observations were based on what he called pain prone patients who have specific psychodynamics regarding pain experiences. ${ }^{[9]}$ Blumer and Heilbornn ${ }^{[45]}$ identified clinical features of pain-prone patients as having desire for surgery, denial of affective and interpersonal problems, engaging in excessive activities before onset of pain, and having a depression masked by pain. The current study included participants from a generally healthy population and not pain prone patients as defined by Blumer and Heilbornn, which might explain the reason for lack of support for second and third hypotheses.

Another reason why the second and third hypotheses were not supported may be the absence of unconscious guilt processing in the present study. According to Freud, guilt must be unconscious to finds its expression as an illness or symptom. ${ }^{[28]}$ For example, utilizing a suppression paradigm, Quartana and Burns ${ }^{[46]}$ found that suppressed anger in experimental settings leads to higher pain sensitivity compared to suppressed of anxiety or no suppression. Moreover, symptom formation of unconscious conflict does not always have to be bodily pain. Maybe, the participants had already punished themselves for their past guilt acts in other ways. Consequently, the participants did not use nocebo pain as a way of expiation in the present study.

Also contrary to the present findings, Bastian, Jetten, and Fasoli ${ }^{[32]}$ found that experiencing physical pain in cold pressor alleviated guilt feelings of the participants induced by writing a memory in which they socially excluded another person. Moreover, guilty participants rated their pain as higher than controls. Several possible explanations for this contradiction can be proposed. First of all, in the present study, the guilt induction was done by asking participants to write memory that they still feel guilty about. However, the context of the guilty act was not fixed. Their expected redemption may be something other than experiencing physical pain, like an eye for an eye approach in the context of the guilty act. Physical pain may be a punishment for socially excluding someone, ${ }^{[32]}$ but not for other types of guilty acts.

Second, previous studies revealed that emotional manipulations such as reading emotionally charged texts, listening to music, and looking at emotional pictures tend to modulate unpleasantness of pain more than pain sensation. ${ }^{[47]}$ In the current study, however, the participants were not asked to differentiate between the unpleasantness of pain and the sensation of pain. It is possible that the experience of writing about a guilt-inducing memory decreased the unpleasantness of pain but not the sensation of pain, which in turn moderated the response given to pain questions. 
Third, De Wall and Baumeister ${ }^{[48]}$ found that social exclusion leads to higher pain threshold and tolerance in the physical pressure application procedure. This effect is called emotional numbness in which social exclusion leads to emotional and physical insensitivity by impairing the functioning of the emotional system. This is because emotional and physical pain experiences share the same physiological mechanisms. ${ }^{[49]}$ Baumeister, Stillwell and Heatherton $^{[50]}$ asserted that guilt may be a form of anxiety resulting from the threat of social exclusion. Similarly, negative evaluation by others and inability to meet cultural standards and norms may lead to self-conscious emotions like shame and guilt. ${ }^{[1]]}$ Therefore, it may be assumed that guilt primes the expectation of social exclusion, and such an expectation may inhibit the effect of guilt feelings on pain ratings.

Fourth, Eisenberger, Lieberman, and Williams ${ }^{[52]}$ examined neural correlates of social exclusion and found anterior cingulate cortex (ACC) activation during social exclusion. It is known that ACC is also activated during experiencing physical pain, ${ }^{\left[{ }^{[3]}\right.}$ and it is related to affective aspects of pain. ${ }^{[54]}$ Interestingly, the patients having cingulotomies (surgical excision of some parts of ACC) for chronic pain complaints continued to feel physical pain, but they were not disturbed by it. ${ }^{[53]}$ Neuroscience studies about guilt feelings suggested that ACC may be a guilt-processing unit in a wider neural network. ${ }^{[5]}$ ACC was also activated as a result of nocebo pain expectations. ${ }^{[21,23]}$ ACC seems to be an intersection area for social pain, physical pain, guilt, and nocebo.

Therefore, it can be asserted if both conscious experience of guilt feelings and physical pain activate ACC, after a conscious guilt induction, simultaneous experience of physical pain may be inhibited. Stated differently, guilt feelings are experienced as an inner unpleasantness, and they override the unpleasantness of nocebo pain. This effect may make the participants less likely to report nocebo manipulation as a pain sensation because the participants may not feel the unpleasantness of pain. On the other hand, unconscious guilt may not activate ACC, and thus, unpleasantness of guilt would be absent. Under such circumstances, guilt may be experienced as physical pain due to shared neural circuitry. For instance, suppression or repression of guilt may produce an effect on ACC and leads to exacerbated physical pain symptoms.
The third hypothesis was that experiencing nocebo pain would be an expiation for the guilt feelings, and participants' guilt feelings would consequently decrease, which was not supported. The results, however, suggested that guilt feelings of the participants in both the nocebo and the no-nocebo conditions decreased from pre-manipulation to post-manipulation, possibly due to the effect of time. The use of Time-Wall Estimation Task may have contributed to this effect. The task was easy to complete, and as a result, it may have increased the selfesteem of the participants. In a study examining the relationship between proneness to guilt and selfesteem, the two were found to be negatively and moderately correlated. ${ }^{[56]}$ Therefore, in the present study, the guilt feelings may have decreased due to increased self-esteem.

Moreover, writing about guilt inducing experience with affective details may serve as an expressive writing task. ${ }^{[57]}$ It was repeatedly found that disclosing an emotional experience by writing or telling about it may reduce distress later in time. ${ }^{[58]}$ Thus, writing about guilt inducing experience with emotional details may have decreased guilt feelings of the participants in time two.

Finally, although there was a significant nocebo manipulation, it may have been too mild to be effective or experienced as punishment, because, mean pain rating of the participants who reported pain was only 1.946 on a 0 to 10 point scale. Bastian, Jetten, and Fasoli, ${ }^{[32]}$ on the other hand, used physical pain manipulation by a cold pressor and found that physical pain can alleviate the effects of guilt. The authors reported that the mean pain ratings for pain condition were 2.79 on a $0-5$ point scale. Therefore, higher degrees of pain that are physically induced may have an effect on guilt feelings, while to lower degrees pain that is not physically induced may not.

\section{Limitations}

The study had several limitations. First of all, the sample size could have been larger. Moreover, the participants were assigned to four conditions by their registration order in the SONA system, because the researchers did not expect any pre-existing differences in independent variables. Yet, random assignment of the participants to the groups could 
have improved internal validity. The study may have lacked an anxiety-provoking experimental environment, as described by Schweiger and Parducci. ${ }^{[14]}$ There are no standard environmental settings or materials to induce nocebo effects; but, further studies can pay attention to characteristics of the environment in which the experiment is conducted and materials used for nocebo manipulation.

Guilt feelings were induced through consciously activated autobiographical memories. There are several other ways of inducing guilt in more experiential and disguised ways. ${ }^{[59]}$ In addition, despite being consciously activated, the participants can be asked to suppress their feelings before nocebo manipulation. ${ }^{[34]}$ Further studies may apply more subtle ways of inducing guilt, or they may examine the effects of unconscious guilt on nocebo pain responses throughout suppression.

\section{Conclusion}

Despite limitations, the results demonstrated once more that mild physical pain could be psychologically induced without any physical stimulation. Therefore, nocebo phenomena may partially explain non-organic somatic complaints of clients. For example, somatic complains of hypochondriasis could stem from the nocebo effect. The patients' anticipation about having an organic illness on some part of the body can actually conceive somatic sensations via anticipation anxiety. Moreover, later, these sensations may be interpreted as serious signs of an illness by the patients.

Effects of unconscious guilt feelings on acute and chronic pain experiences still require further investigation. Hypothetically, unconscious or suppressed guilt feelings may exacerbate experiencing physical pain, and they may be a mechanism behind chronic pain complaints. Also, uncovering unconscious guilt feelings in psychotherapy practices may alleviate the client's physical pain complaints. Considering high comorbidity between depression and chronic pain, ${ }^{[60-64]}$ neural evidence for the prominent role of guilt feelings in depressive disorders, ${ }^{[65]}$ and the inhibiting effect of positive emotions on pain perception, ${ }^{[6]}$ emotional health of clients with chronic pain problems should be a fundamental target of psychotherapeutic interventions.
Chronic pain problems have been a controversial topic, and their investigation should involve a biopsychosocial approach. Yet, existing research seems to be rather narrow, focusing only on the psychological or the biological mechanisms. A more holistic understanding of the patients' experiences can benefit both the researchers and the clinicians.

Acknowledgements: EEG Cap used in the study was provided by Balkar Erdoğan from Middle East Technical University Electrical and Electronics Engineering Department. Assoc. Prof Ahmet Uysal and Assoc. Prof. Tolga Esat Özkurt provided significant contributions and feedbacks for design of the study. Undergraduate psychology students Zeynep Bilsel, Sinem Çelik, and Büşra Karagöz worked voluntarly during data collections procedures.

Ethics Committee Approval: Ethical approval for this study was provided by the Research Center for Applied Middle East Technical University (date: 08.02.2017, number: 28620816/64).

Conflict-of-interest issues regarding the authorship or article: None declared.

Peer-rewiew: Externally peer-reviewed.

Financial Disclosure: The authors declared that this study has received no financial support.

\section{References}

1. Crook J, Tunks E, Rideout E, Browne G. Epidemiologic comparison of persistent pain sufferers in a specialty pain clinic and in the community. Arch Phys Med Rehabil 1986;67(7):451-5.

2. Andersson HI, Ejlertsson G, Leden I, Rosenberg C. Chronic pain in a geographically defined general population: studies of differences in age, gender, social class, and pain localization. Clin J Pain 1993;9(3):174-82. [CrossRef]

3. Blyth FM, March LM, Brnabic AJ, Jorm LR, Williamson M, Cousins MJ. Chronic pain in Australia: a prevalence study. Pain 2001;89(2-3):127-34. [CrossRef]

4. Johannes CB, Le TK, Zhou X, Johnston JA, Dworkin RH. The prevalence of chronic pain in United States adults: results of an Internet-based survey. J Pain 2010;11(11):1230-9.

5. van Hecke O, Torrance N, Smith BH. Chronic pain epidemiology and its clinical relevance. Br J Anaesth 2013;111(1):13-8.

6. Erdine S, Hamzaoğlu O, Özkan Ö, Balta E, \& Domac M. Pain prevalance among adults in Turkey. Ağrı, 2001;13(2):22-30.

7. Melzack R. Evolution of the neuromatrix theory of pain. The Prithvi Raj Lecture: presented at the third World Congress of World Institute of Pain, Barcelona 2004. Pain Pract 2005;5(2):85-94. [CrossRef]

8. IASP. Guide to Pain Management in Low-Resource Settings. Traue HC, Jerg-Bretzke L, Pfingsten M, Hrabal V. Psycho- 
logical Factors in Chronic Pain. Available at: http://ebooks. iasp-pain.org/guide_to_pain_management_in_low_resource_settings.

9. Mayou R. Medically unexplained physical symptoms. BMJ 1991;303(6802):534-5. [CrossRef]

10. Engel GL. Psychogenic pain and pain-prone patient. Am J Med 1959;26(6):899-918. [CrossRef]

11. Apkarian AV, Baliki MN, Geha PY. Towards a theory of chronic pain. Prog Neurobio. 2009;87(2):81-97. [CrossRef]

12. Benedetti F, Lanotte M, Lopiano L, Colloca L. When words are painful: unraveling the mechanisms of the nocebo effect. Neuroscience 2007;147(2):260-71. [CrossRef]

13. Data-Franco J, Berk M. The nocebo effect: a clinicians guide. Aust N Z J Psychiatry 2013;47(7):617-23. [CrossRef]

14. Schweiger A, Parducci A. Nocebo: the psychologic induction of pain. Pavlov J Biol Sci 1981;16(3):140-3.

15. Johansen O, Brox J, Flaten MA. Placebo and Nocebo responses, cortisol, and circulating beta-endorphin. Psychosom Med 2003;65:786-90. [CrossRef]

16. Colloca $L$, Sigaudo $M$, Benedetti $F$. The role of learning in nocebo and placebo effects. Pain 2008;136(1-2):211-8.

17. Vögtle E, Barke A, Kröner-Herwig B. Nocebo hyperalgesia induced by social observational learning. Pain 2013;154(8):1427-33. [CrossRef]

18. Jensen KB, Kaptchuk TJ, Kirsch I, Raicek J, Lindstrom KM, Berna $C$, et al. Nonconscious activation of placebo and nocebo pain responses. Proc Natl Acad Sci U S A 2012;109(39):15959-64. [CrossRef]

19. Petersen GL, Finnerup NB, Colloca L, Amanzio M, Price DD, Jensen TS, Vase $L$. The magnitude of nocebo effects in pain: a meta-analysis. Pain 2014;155(8):1426-34. [CrossRef]

20. Benedetti F, Amanzio M, Casadio C, Oliaro A, Maggi G. Blockade of nocebo hyperalgesia by the cholecystokinin antagonist proglumide. Pain 1997;71(2):135-40. [CrossRef]

21. Benedetti F, Amanzio M, Vighetti S, Asteggiano G. The biochemical and neuroendocrine bases of the hyperalgesic nocebo effect. J Neurosci 2006;26(46):12014-22. [CrossRef]

22. Keltner JR, Furst A, Fan C, Redfern R, Inglis B, Fields HL. Isolating the modulatory effect of expectation on pain transmission: a functional magnetic resonance imaging study. J Neurosci 2006;26(16):4437-43. [CrossRef]

23. Chua P, Krams M, Toni I, Passingham R, Dolan R. A functional anatomy of anticipatory anxiety. Neuroimage 1999;9(6 Pt 1):563-71. [CrossRef]

24. Hsieh JC, Stone-Elander S, Ingvar M. Anticipatory coping of pain expressed in the human anterior cingulate cortex: a positron emission tomography study. Neurosci Lett 1999;262(1):61-4. [CrossRef]

25. Tangney JP, Wagner P, Gramzow R. Proneness to shame, proneness to guilt, and psychopathology. J Abnorm Psychol 1992;101(3):469-78. [CrossRef]

26. Breuer J, Freud S, Strachey J. Studies on hysteria. New York : Basic Books; 1957.

27. Blum A. Shame and guilt, misconceptions and controversies: A critical review of the literature. Traumatology 2008:14;91-102. [CrossRef]
28. Freud S. The neuro-psychosis of defence. In: Strachey J, editor. The Standard Edition of the Complete Psychological Works of Sigmund Freud. New York: W.W. Norton \& Company; 1976.

29. Freud S. The Ego and The Id. In: Phillips A, Reddick J, editors. Beyond the pleasure principle and other writings. London, England: Penguin Books; 2003.

30. Freud S. Some character types met in psycho-analytic work. In: Strachey J editor. The Standard Edition of the Complete Psychological Works of Sigmund Freud, Volume XIV (1914-1916): On the History of the Psycho-Analytic Movement, Papers on Metapsychology and Other Works. London, England: Hogard Press; 1957. p. 309-33.

31. Freud S. Civilization and its discontents. New York: W. W. Norton; 2010.

32. Bastian B, Jetten J, Fasoli F. Cleansing the soul by hurting the flesh: the guilt-reducing effect of pain. Psychol Sci 2011;22(3):334-5. [CrossRef]

33. Nelissen RM. Guilt-induced self-punishment as a sign of remorse. Social Psychological and Personality Science 2012:3;139-44. [CrossRef]

34. Mete HE, Noyan A, Sertöz ÖÖ. Psychosocial aspects of pain. Agri 2006;18(1):20-5.

35. Burns JW, Quartana PJ, Bruehl S. Anger inhibition and pain: conceptualizations, evidence and new directions. J Behav Med 2008;31(3):259-79. [CrossRef]

36. Dersh J, Polatin PB, Gatchel RJ. Chronic pain and psychopathology: research findings and theoretical considerations. Psychosom Med 2002;64(5):773-86. [CrossRef]

37. Gatchel RJ, Peng YB, Peters ML, Fuchs PN, Turk DC. The biopsychosocial approach to chronic pain: scientific advances and future directions. Psychol Bull 2007;133(4):581-624.

38. Watson D, Clark LA, Tellegen A. Development and validation of brief measures of positive and negative affect: the PANAS scales. J Pers Soc Psychol 1988;54(6):1063-70.

39. Gençöz, T. Pozitif ve negatif duygu ölçeği: Geçerlik ve güvenirlik çalışması. Türk Psiko Der 2000:15(46);19-6.

40. Englund CE, Reeves DL, Shingledecker CA, Thorne DR, Wilson KP, Hegge FW. Unified Tri-Service Cognitive Performance Assessment Battery (UTC-PAB) I. Design and Specification of the Battery; Report No. 87-10. Naval Health Research Center, Naval Medical Research and Development Command; 1987. [CrossRef]

41. Mayers A. Introduction to Statistics and SPSS in Psychology. Pearson; 2013.

42. Manikandan S. Data transformation. J Pharmacol Pharmacother 2010;1(2):126-7. [CrossRef]

43. Spiegel H. Nocebo: the power of suggestibility. Prev Med 1997;26(5 Pt 1):616-21. [CrossRef]

44. McCambridge J, de Bruin M, Witton J. The effects of demand characteristics on research participant behaviours in non-laboratory settings: a systematic review. PLoS One 2012;7(6):e39116. [CrossRef]

45. Blumer D, Heilbronn M. The pain-prone disorder: a clinical and psychological profile. Psychosomatics 1981;22(5):3957. [CrossRef] 
46. Quartana PJ, Burns JW. Painful consequences of anger suppression. Emotion 2007;7(2):400-14. [CrossRef]

47. Villemure $C$, Bushnell MC. Cognitive modulation of pain: how do attention and emotion influence pain processing? Pain 2002;95(3):195-9. [CrossRef]

48. DeWall CN, Baumeister RF. Alone but feeling no pain: Effects of social exclusion on physical pain tolerance and pain threshold, affective forecasting, and interpersonal empathy. J Pers Soc Psychol 2006;91(1):1-15. [CrossRef]

49. Macdonald G, Leary MR. Why does social exclusion hurt? The relationship between social and physical pain. Psychol Bull 2005;131(2):202-23. [CrossRef]

50. Baumeister RF, Stillwell AM, Heatherton TF. Guilt: an interpersonal approach. Psychol Bull. 1994;115(2):243-67.

51. Wong Y, Tsai T. Cultural models of shame and guilt. In: The Self-Conscious Emotions: Theory and Research. Guilford Press 2007:209-23.

52. Eisenberger NI, Lieberman MD, Williams KD. Does rejection hurt? An FMRI study of social exclusion. Science 2003;302(5643):290-2. [CrossRef]

53. Foltz EL, White LE. The role of rostral cingulumotomy in "pain" relief. Int J Neurol 1968;6(3-4):353-73.

54. Rainville P, Duncan GH, Price DD, Carrier B, Bushnell MC. Pain affect encoded in human anterior cingulate but not somatosensory cortex. Science 1997;277(5328):968-71.

55. Jankowski KF, Takahashi H. Cognitive neuroscience of social emotions and implications for psychopathology: examining embarrassment, guilt, envy, and schadenfreude. Psychiatry Clin Neurosci 2014;68(5):319-36. [CrossRef]

56. Strelan P. Who forgives others, themselves, and situations? The roles of narcissism, guilt, self-esteem, and agreeable- ness. Pers Individ Dif 2007;42:259-69. [CrossRef]

57. Pennebaker JW. Expressive Writing in Psychological Science. Perspect Psychol Sci 2018;13(2):226-9. [CrossRef]

58. Lepore SJ, Smyth JM. The Writing Cure, How Expressive Writing Promotes Health and Emotional Well-being. Amer Psychological Assn; 2002. [CrossRef]

59. Rebega OL., Apostol L, Benga O, Miclea M. Inducing Guilt: A Literature Review. Procedia Soc Behav Sci 2013;78:53640. [CrossRef]

60. Hancı V, İkiz B, Günenç E, Sangare M, Özbilgin Ş, Erkin Y, et al. An evaluation of the psychosocial characteristics of patients admitted to a pain clinic and their relatives. Agri 2015;27(3):143-8.

61. Tarakcı E, Zenginler Y, Kaya Mutlu E. Chronic pain, depression symptoms and daily living independency level among geriatrics in nursing home. Agri 2015;27(1):35-41. [CrossRef]

62. Güleç G, Güleç S. Pain and pain behavior. Agri 2006;18(4):59.

63. Katon W, Egan K, Miller D. Chronic pain: lifetime psychiatric diagnoses and family history. Am J Psychiatry 1985;142(10):1156-60. [CrossRef]

64. Magni G, Moreschi C, Rigatti-Luchini S, Merskey H. Prospective study on the relationship between depressive symptoms and chronic musculoskeletal pain. Pain 1994;56(3):289-97. [CrossRef]

65. Green S, Lambon Ralph MA, Moll J, Deakin JF, Zahn R. Guiltselective functional disconnection of anterior temporal and subgenual cortices in major depressive disorder. Arch Gen Psychiatry 2012;69(10):1014-21. [CrossRef]

66. Rhudy JL., Meagher MW. The role of emotion in pain modulation. Current Opinion in Psychiatry 2001;14(3):241-5. 